\title{
Oil Revenue and Economic Growth; an Empirical Evidence from Nigeria
}

\author{
Ewubare Dennis Brown ${ }^{\# 1}$, Uzoma Chidoka Nnamaka ${ }^{* 2}$ \\ ${ }^{\# 1 \& * 2}$ Department of Agricultural and Applied Economics, Rivers State University, Port Harcourt, Nigeria
}

\begin{abstract}
The study examined the effects of oil revenue on economic growth in Nigeria between 1980 and 2017. Time series data were sourced from secondary sources on Gross Domestic Product, Oil Revenue, Oil Rent and Domestic Price of Petrol. The analysis started by analyzing the descriptive statistics of the series and proceeded to examination of the stochastic characteristics of each time series by testing their stationary using Augmented Dickey-Fuller test. The ARDL model was used to estimate the coefficients of the parameters for both the short-run and the long-run. The Fstatistics obtained from the bounds co-integration test shows a stable long run relationship between the variables. Findings from the study showed that in the long run, oil revenue and oil rent impacted on GDP positively although not significantly. In the short run however, both variables retarded economic growth in Nigeria. This goes a long way to show that the enormous windfall from crude oil in the nation has been mismanaged. The domestic price of petrol impacted positively on economic growth both in the long run and short run. The study therefore recommends a judicious use of the revenue generated from the oil sector to provide long term sustainable economic growth. In addition, due to the volatility and uncertainty in the oil sector in Nigeria, government should embark on a realistic diversification plan to alternative sectors of the economy to enhance the productive base of the nation seeing that crude oil is an exhaustible asset.
\end{abstract}

\section{INTRODUCTION}

Countries that are endowed with abundant natural resources can have remarkable growth rates or slow growth rates depending on how the proceeds from the resources are utilized. One of such natural resources is crude oil (Olayungbo\&Adediran, 2017). Crude oil (also known as black gold) is an important natural resource as it is a major source of revenue in Nigeria and in the world at large. The exploration of crude oil is critical to the development of economies around the world. Apart from its reputation as the major revenue earner for Nigeria, oil is a basic raw material for a wide range of commodities including petrol and diesel for cars and engineering equipment, asphalt road surfaces, tars, tyres, solvents, deodorants, crayons, glue amongst a wide range of other products (Ojapinwa and Ejumedia, 2012). Oil is used as an important benchmark in the politics and diplomacy of nations as it serves as a gateway for foreign exchange earning to oil exporting countries. In addition, it is a major determinant of the value of the dollar in international market (Opaleye et al, 2018).

Nigeria is the largest oil producer of Sub-Saharan Africa and the $6^{\text {th }}$ in the Organisation of Petroleum Exporting Countries (Ogbonna and Ebimobowie, 2012). Prior to the oil boom in Nigeria, Agriculture was the mainstay of the economy and the greatest foreign exchange earner. Its product was the major constituent of Nigeria's non-oil exports. The shares of these products both processed and unprocessed in total value of non-oil exports was as high as 70 percent (CBN, 2011). Nigeria was not particularly a rich country until the 1973-1974 oil price rise which made crude oil account for 80 percent of all government revenue and more than 90 percent of the country's export. The nation became a monolithic economy ever since the oil boom era of the 1970's and has continued to enjoy "crude cash" without an adequate policy to put the nation on a firm foundation for steady growth. This rise in oil price triggered queries concerning the link between oil price and economic growth in both oil producing and non-oil producing countries. When there is a rise in the price of crude oil, it is considered to be beneficial to oil exporting countries while the reverse is the case in oil importing countries. The argument here is that oil price leads to a transfer of income from importing countries to exporting ones which in turn improves the real national income of 
the later. However, a persistent rise in oil price can be detrimental to oil exporting nations in the sense that the GDP growth rate in oil consuming nations may reduce thereby leading to a decline in the oil demand by those nations. Whilst crude oil assumed greater prominence as a dynamic sector, other sectors of the economy suffered neglect. Nigeria's GDP per capita was $\$ 1.113$ in 1970 but only $\$ 1,084$ in 2000 and during the same period, its poverty rate (measured as the share of the population subsisting on less than US\$1 per day) increased from about 36 percent to 70 percent (Subramanian et al, 2003).

Nigeria has moved from an oil boom through an economic emergency which metamorphosed into a full-blown SAP to perhaps an oil doom sliding from an oil rich country in the 1970's to one of the poorest countries in the world. While crude oil accounts for over 90 percent Nigeria's export earnings with its attendant huge revenue generating capacity, mass poverty is a lot more now than at independence (Okowa, 1997). Nigeria is faced with multiple problems of high inflation rates, unfavorable balance of payment position, increased unemployment rate, slow economic growth amongst other macroeconomic problems. For instance, while oil revenue increased from N166.6 million to N8564.4 million between 1970 and 1981, inflation rate rose from 13.8 percent to 20.9 percent. Between 2000 and 2011, oil revenue shot up from N1,591,700 million to N8,848,615 million. In that same period, inflation rate rose from 6.9 percent to as high as 18.9 percent in 2001. Furthermore, unemployment rate was 13.1 percent in 2000 and by 2011, the rate had increased to 23.9 percent (CBN, 2012). The gains from crude oil have not commensurately improved external reserves in Nigeria. The nation's external reserves dropped from $\$ 53.6$ billion in 2008 to $\$ 30.9$ billion in 2015 before peaking up to $\$ 39.3$ billion in 2018 (CBN, 2019). It is sad to note that oil producing countries still receive financial aids and support from developed countries despite the huge revenue accruing to them from oil (Agnihotri, 2015). For instance, in 2008, when the price of crude oil was US\$100 per barrel, oil producing countries like Angola, Algeria, Egypt and Nigeria received the sum of US\$369 million, US $\$ 324.8$ million, US $\$ 1.7$ billion and US\$1.29 billion respectively in aids and assistance from multilateral institutions (Ewubare\&Obayori, 2019). Increase in oil wealth was expected to improve the overall living condition of the average Nigerian but the reverse has been the case. This has led to the quest to carry out a study on oil revenue and economic growth in Nigeria. The objectives of this study therefore are to; examine the impact of oil revenue on economic growth in Nigeria, ascertain the impact of oil rent on economic growth in Nigeria, determine the impact of the domestic price of petrol on economic growth in Nigeria. Apart from the introduction, the rest of this study is structured into literature review, materials and methods, results and discussion; and conclusion.

\section{LITERATURE REVIEW}

\subsection{Theoretical Review}

\section{Resource Curse Theory}

The resource curse refers to the negative relationship existing between natural resource endowment and social and economic development. The theory explains that countries that are endowed with substantial natural resources not only failed to use their abundant resources to promote economic and social development but tend to perform poorly compared to countries that are less endowed. Resource rich countries are usually faced with social, economic and political problems with cases of poverty, environmental degradation, corruption and war. According to Collier and Hoeffler (2002), 23 percent of states dependent on oil exports have experienced civil war in any five-year period, a figure that dwarfs the 0.6 percent for countries without natural resources.

An explanation for the resource curse is the poor economic linkages between resources and non-resource sectors, failing to develop other sectors of the economy because of the concentration on only a handful of industries which have direct bearing with their natural endowments. The resource curse paradox is rooted in the Dutch disease which owes its origin to the experience of the Netherlands in the 1960's with the discovery of natural gas in the North Sea which led to a rise in the real exchange rate with its adverse effect on the agricultural and manufacturing sectors thereby lowering the overall economic growth.

Of all natural resources, oil has a high risk of civil conflict due tothe shocks to which the government and the national economy are exposed to and the large rents it offers (Collier and Hoeffler, 2005), Fearon and Laiton, 2005).

(C) 2019, IJSMS 


\subsection{Crude Oil and Economic Growth Profile of Nigeria}

In Nigeria, Shell BP discovered oil in the Niger Delta region, precisely Oloibiri in 1956. Nigeria's first consignment of crude oil was delivered to Europe in 1958 (Okonma, 1997). The nation did not realize significant quantities of crude oil until the construction of pipelines and terminals on the Atlantic coast of bonny island 1965. The oil industry in Nigeria is made up of the upstream (which involves exploration and production) and the downstream (which involves refining, marketing and distribution) and joined the ranks of oil producers in 1958 when the first oil field came on stream producing 5,100 barrels per day (bpd). Nigeria officially joined the Organization of Petroleum Exporting (OPEC) in 1971 and established the Nigerian National Petroleum Corporation (NNPC) in 1977; a state controlled company which is a major player in both the upstream and the downstream sectors (NNPC, 2010).

The oil industry has become the mainstay of the Nigerian economy, contributing massively to gross domestic product and accounting for the bulk of federal government revenue and foreign exchange earnings since early 1970.In 2000 oil and gas exports accounted for more than $98 \%$ of export earnings and about $83 \%$ of federal government revenue. Nigeria's oil reserves are estimated to be about 35 billion barrels; natural gas reserves are well over 100 trillion $\mathrm{ft}(2,800 \mathrm{~km})$. In the middle of 2001, Nigeria's crude oil production was averaging around 2.2 million barrels $(350,000 \mathrm{mi})$ per day (Odularu, 2008). Nigeria gained US $\$ 390$ billion in oil-related fiscal revenue over the period 1971-2005 Asekomehet al (2014). In June 2014, the United States of America announced its reduction on the purchase of crude oil from Nigeria thereby making the country to drop from the fifth to sixth position which it occupied in the list of highest suppliers of crude to the US. Oil prices were fairly stable up until mid-2014 when prices started falling from $\$ 114$ per barrel to below $\$ 50$ per barrel in 2015, dipping further below $\$ 35$ per barrel.

For a mono-product economy like Nigeria, it is not surprising that a sudden and sustained decline in the price of the product will impact the nation's revenue negatively. The average daily crude oil production in the second quarter 2014 was recorded 2.21 million barrels per day (bpd) as against 2.11 million bpd in the corresponding quarter in of 2013 , representing a 4.7 per cent increase. The price of crude oil increased significantly from an average price of $\$ 104.31$ in the second quarter of 2013 to $\$ 112.25$ in the corresponding quarter in 2014 (NBS, 2014). According to data released by the Nigerian Extractive Industries Transparency Initiative (NEITI), Nigeria has consistently recorded significant declines in crude oil output since the end of the fourth quarter of 2015. Crude oil production in the nation dropped from 2.17 million bpd in the fourth quarter of 2015 to 1.6 million bpd. The drop in crude oil took its toll on oil export as the total crude oil revenue shortfall in the first quarter of 2016 was $\$ 268.58$ million. This loss in oil revenue was majorly attributed to the attacks on oil installations particularly in the Niger Delta region of the nation.

In September 2016, the members of the OPEC reached an agreement to ease the global glut by cutting oil production quota to 32.5 million bpd from the current production of 33.24 million bpd after a two-year refusal to lower oil output in the faces of falling prices. This decision put the Nigerian economy on alert as it depends on oil sales for bulk of its revenue especially in the face of recession. Surprisingly, Oil export revenue rose by 30 per cent from \$26 billion in 2016 to $\$ 34$ billion in 2017 according to the OPEC revenues fact sheet released by the energy information administration. Brent crude (which is the global oil benchmark against which Nigeria's oil is priced) rose from $\$ 53$ per barrel (pb) at the end of 2017 to $\$ 66.87 \mathrm{pb}$ in early 2018. The increase in oil prices continued in 2018, with Brent peaking up to $\$ 80 \mathrm{pb}$ in the middle of 2018 , the highest value since 2014 . Consequently, oil revenue accounted for 71 percent of the federally collected revenue which rose from N7.3 trillion in 2017 to N13.3 trillion in 2018. The oil sector in general recorded a real GDP growth rate of -1.62 percent in the fourth quarter of 2018 indicating a decline of -12.81 percent point relative to the growth rate observed in the corresponding quarter of 2017. The oil sector contributed 7.06 percent to real GDP in the last quarter of 2018 as against the 7.35 percent contribution in the corresponding quarter of 2017. Unfortunately, the nation has continued to import refined petroleum products after many years of crude oil extraction. 


\subsection{Empirical Literature}

A number of studies on oil revenue- economic growth nexus in Nigeria exist in the literature. For instance, Akanni (2007) carried out a study on oil wealth and economic growth in 47 oil exporting African countries using a panel data regression analysis spanning from 1970 to 2000. The study showed the theoretical and empirical analysis of the channels of transmission of resource curse of natural resources on growth in African countries. It was evident from the findings that the resource curse was valid in the countries studied although exchange rate and the Dutch disease syndrome did not provide the explanation for the resource curse in the countries.

Odularu (2008) investigated on the impact of crude oil on Nigerian economic performance using the Ordinary Least Square regression method. The findings from the studyrevealed that crude oil consumption and export have contributed to the improvement of the Nigerian economy. The study therefore concluded that government should implement policies that would stimulateprivate sector participation in the crude oil sector in the country.

In their work, Ogbonna and Ebimobowei (2011) examined the impact of petroleum revenue on the Nigerian economy for the period 1970 to 2009. Findings from their study showed that petroleum revenue positively affects the GDP and per capita income in Nigeria. The relationship between oil revenue and inflation was however negative. In conclusion, the study recommended the proper management and utilization of revenue in order to achieve long run growth and development.

Adedokun (2012) analyzed the effect of oil export revenue on economic growth in Nigeria for the period, 1975 to 2009. Empirical findings from the study revealed that oil export revenue had a positively significant effect on growth both in the short-term and long-term. The study further showed that world crude oil prices primarily determines the foreign exchange earnings in Nigeria.

Using a multivariate co-integration VAR model, Akinlo (2012) carried out a study onthe importance of oil in the development of the Nigerian economy covering the period, 1960 to 2009. The study utilized quarterly time series data on GDP indices of the five sectors namely: agriculture, manufacturing, building\& construction, oil and trade \& services to set up the VAR model. The study found that the five subsectors were co-integrated and that the oil caused other non-oil sectors to grow. However, oil had adverseeffect on the manufacturing sector. Granger causality test found bidirectional causality between oil andmanufacturing, oil and building/construction, manufacturing and building/construction, manufacturing andtrade/services, and agriculture and building/construction. It also confirmedunidirectional causality from manufacturing to agriculture, and trade/services to oil.No causality was found between agriculture and oil,likewise between trade/services and building/construction.In conclusion, the study recommended appropriate regulatory and pricing reforms in the oil sector in order to integrate it into the economy, and as well reverse the negative impact of oil on the manufacturing sub sector in Nigeria.

Investigating the downstream sector, Auwal and Mamman (2012) carried out an assessment of petroleum products supply in Nigeria. The study employed the Vector Auto regression (VAR) model technique using monthly data spanning from 2005 to 2010 to investigate the impact of the petroleum products supplyand domestic prices on the domestic distribution. Findings from the study showed thatthe independent variables are responsible for thevariations in petroleum products distributedbecause of their non-zero coefficients. Based on the lagged and dynamic long-run equilibrium,domestically refined and prices of petroleum products remained insensitive to the quantity distributed, while theimported quantity, though with a low coefficient and weak correlation, remained the key mode of supply that iscurrently sustaining the economy.

Ogbonna and Appah (2012) carried out an empirical analysis on petroleum income and the Nigerian economy for the period 2000 to 2009. The study used simple regression models to evaluate whether the variation in GDP wasexplained by the oil revenue. Findings from the study showed that oil revenue has a positive and significant relationship with GDP and per capita income, but a positive andinsignificant relationship with inflation. In the same vein, petroleum profit tax/royalties had a positive and significant relationship with GDP and per capita income, but a negative and insignificant relationship with inflation. The study also revealed that licensing fees has a positive but insignificant relationship with GDP, per capita income and inflation, respectively. Based on these findings, the 
studyconcluded that petroleum income (oil revenue and petroleum profit tax/royalties) had positively and significantly impacted theNigerian economy when measured by GDP and per capita income.

Oladipo and Fabayo (2012) carried out a study on global recession and the oil sector, basing on its effects on economic growth in Nigeria. Analysis from the study showed a negatively significant relationship between GDP and domestic oil consumption and oil export in the country. The result further showed that global recession led to a decline in the oil sector. In conclusion, the studyrecommended the deregulation of the oil sector for efficient performance, and also the implementation of more rigorous policies that will reduce global effects on the sector seeing that it constitutes a large proportion of national income.

In another study, Baghebo and Atima (2013) examined the impact of petroleum on economic growth in Nigeria using data that spanned from 1980 to 2011 sourced fromthe CBN Statistical Bulletin andtransparency international Agency annual publications. The study employed some econometricapproaches in estimating the relationship between oil export, foreign direct investment, corruption index, external debt and economic growth in Nigeria. Analysis from the study showed that FDI impacted positively and significantly on Real GDP. Oil revenue on the other hand impacted negatively and significantly on Real GDP implying that the Dutch disease phenomenon exists in Nigeria. Corruption index had a negative and statistically insignificant impact on Real GDP. In conclusion,the study recommends the implementation of thepetroleum industry bill as it will address the problems of corruption and the negative impact of oil revenue onGDP.

Eravwoke, Alobari and Ukavwe (2014) carried out an investigation on crude oil export and its impact on economic growth in Nigeria. The study employed the ordinary least squares (OLS) regression technique in the estimation. Findings from thestudy showed the existence of a significant inverse relationship between crude oil exports and economic growth in Nigeria. The implicationis that oil export is a significant factor that is capable of transforming the growth of an economy.

In their study, Aregbeyen and Kolawole (2015) examined the relationship between oil revenue, government spending and economic growth in Nigeria for a 33-year time period spanning from 1980 to 2012. The study employed the ordinary least squares (OLS), co-integration, vector error correction model (VECM) and Granger causality techniques in their estimation. Their research showed that no causality exists between government spending and growth. Government spending and economic growth however were Granger caused and largely influenced by oil revenue. In conclusion, the study recommended that for government to boost economic growth in Nigeria, expenditure on capital projects should be increased and also efforts should be made to increase the potential and output of other sectors of the economy.

Attamah (2015) set out in a study to investigate the impact of Oil Wealth on economic growth in Nigeria for the period 1980 to 2012. The study adopted the OLS econometric technique in the estimation. The result from the study showed that the oil sector contributed positively to economic growth. However based on comparative analysis, the agricultural sector contributed more to GDP than the oil sector. The paper therefore recommended that the Nigeriangovernment should pursue the policy of revenue base diversification. In addition, the study also recommended the utilization of petroleum resources to drive industrialization.

In analyzing the impact of oil on the growth of oil exporting countries, Fuinhas, Marques and Couto (2015) using the fixed effects method in a panel research for a 40-year time period. Findings from their study showed that oil production improved economic growth in the short run. Also, primary energy consumption impacts positively on economic growth both in the short run and also in the long run while oil prices exerted a positive effect on growth in the short run. However, oil rents depressed economic growth both in the short and long run.

Nwoba\&Abah(2017)examined the impact of crude oil revenue on economic growth in Nigeria for the period 1960 to 2010 using the ordinary least square (OLS) regression analysis. Findings from the study revealed a long run positive relationship between oil revenue and gross domestic product. 
Maku, Adetowubo\&Aduralere (2018)set out in their study to investigate the impact of petroleum pump price on human welfare in Nigeria for the period 1990 to 2015 using the autoregressive distributed lag (ARDL)/Bounds approach. The result of the study showed thatpremium motor spirit price and dual purpose kerosene price exert a significantly negative impact on human welfare both in the short run and in the long run. The study concluded that for human welfare to increase, there must be a drop in the prices of premium motor spirit and dual purpose kerosene and also inflation rate in Nigeria. Also, thegovernment and relevant agencies should ensure that petroleum pump prices be regulated because they have a long way on the market.

Though there exists a plethora of empirical studies on the effects of oil revenue on economic growth in Nigeria, they however did not examine the effect of oil revenue on economic growth in Nigeria including oil rent and domestic price of petrol from 1990 to 2018 in a single study. This is the identified gap this study has targeted to fill.

\section{MATERIALS AND METHOD}

\subsection{Nature and Source of Data}

The dataset for this research work was time series data from secondary sources spanning from 1990 to 2018 . The data was sourced from Central Bank of Nigeria (CBN) statistical bulletin and World Bank database.

\subsection{Model Specification}

The model has its independent variables as oil revenue, oil rent as well as domestic price of petrol while gross domestic product is the dependent variable. The functional form of the model is as follows:

$\mathrm{GDP}=\mathrm{f}(\mathrm{ORV}, \mathrm{ORT}, \mathrm{DPP})$

It was further specified in econometric form as follows:

$\mathrm{LGDP}_{\mathrm{t}}=\alpha_{0}+\alpha_{1} \mathrm{LORV}_{\mathrm{t}}+\mathrm{a}_{2} \mathrm{LORT}_{\mathrm{t}}+\alpha_{3} \mathrm{LDPP}_{\mathrm{t}}+\mathrm{U}_{\mathrm{t}}$

GDP $=$ Gross Domestic Product,$\quad$ ORV $=$ Oil Revenue, ORT $=$ Oil Rent, DPP $=$ Domestic Price of Petrol, $\mu_{\mathrm{t}}=$ Random Variable, $\alpha_{0}=$ Intercept $, \alpha_{1}, \alpha_{2}, \& \alpha_{3}=$ Estimated parameters of the independent variables.

Where: GDP $=$ Gross Domestic Product

$$
\begin{aligned}
& \text { ORV = Oil Revenue } \\
& \text { ORT = Oil Rent } \\
& \text { DPP = Domestic Price of Petrol } \\
& \mu_{\mathrm{t}}=\text { Random Variable } \\
& \mathrm{a}_{0}=\text { Intercept }
\end{aligned}
$$

$\alpha_{1}-\alpha_{3}=$ Estimated parameters of the independent variables

\subsection{Method of Data Analysis}

\section{Autoregressive Distributed Lags Model}

The Autoregressive Distributed Lags (ARDL)/bound test approach to co-integration, proposed by Pesaranet al (2001) was adopted in this study to determine whether the underlying time series variables has long run relationship. The null hypothesis of no co-integration is tested against the alternative hypothesis of co-integration. Restating equation (2) as an ARDL model we have: 
$\Delta \mathrm{LGDP}_{\mathrm{t}}=\pi_{0}+\sum_{i=1}^{p} \theta_{1 \mathrm{i}} \Delta \mathrm{LGDP}_{\mathrm{t}-1}+\sum_{i=0}^{p} \theta_{2 \mathrm{i}} \Delta \mathrm{LORV}_{\mathrm{t}-1}+\sum_{i=0}^{p} \theta_{3 \mathrm{i}} \Delta \mathrm{LORT}_{\mathrm{t}-1}+\sum_{i=0}^{p} \theta_{4 \mathrm{i}} \Delta \mathrm{LDPP}_{\mathrm{t}-1}+\delta_{1} \mathrm{LGDP}_{\mathrm{t}-1}+$ $\delta_{2} \mathrm{LORV}_{\mathrm{t}-1}+\delta_{3} \mathrm{LORT}_{\mathrm{t}-1}+\delta_{4} \mathrm{LDPP}_{\mathrm{t}-1}+\varepsilon_{\mathrm{t}}$

Where $\Delta$ denotes the difference operator

$\pi_{0}$ is the vector of the intercept

$\theta_{1}-\theta_{6}$ is the short run dynamic coefficient

$\delta_{1}-\delta_{2}$ is the long run coefficients of the explanatory variables

$\varepsilon_{\mathrm{t}}$ is the error term

The null hypothesis of no co-integration is tested under the asymptotic distribution of the F-statistic. From the ARDL model in equation (2), the null and the alternative hypotheses are expressed respectively below:

$\mathrm{H}_{0}: \delta_{1}=\delta_{2}=\delta_{3}=\delta_{4}=\delta_{5}=\delta_{6}$

$\mathrm{H}_{1}: \delta_{1} \neq \delta_{2} \neq \delta_{3} \neq \delta_{4} \neq \delta_{5} \neq \delta_{6}$

Pesaranet al (2001) reported two sets of critical values. One critical value requires that all the variables in the ARDL model are $\mathrm{I}(0)$, while, the other assumes that the variables are $\mathrm{I}(1)$. If the computed F-statistic is greater than the upper bound I(1) of the critical value, the null hypothesis of no co-integration would be rejected. However, if the falls below the lower bound, the null hypothesis of no co-integration cannot be rejected. The test is however inconclusive if the F-statistic falls in between the bounds (Ewubare and Uzoma, 2019).

\section{$4 \quad$ RESULT AND DISCUSSION}

\subsection{Descriptive Statistics on variables of the Study}

The summary of the descriptive statistics for the variables in the study are presented in the table below.

\begin{tabular}{|l|c|c|c|c|}
\hline Statistics & GDP & ORV & ORT & DPP \\
\hline Mean & 36055.83 & 2933486. & 15.65653 & 51.97414 \\
\hline Maximum & 127762.6 & 6530630. & 34.32786 & 145.0000 \\
\hline Minimum & 499.6800 & 71887.10 & 1.153408 & 0.600000 \\
\hline Std. Dev. & 39581.11 & 2355935. & 11.11 & 45.03 \\
\hline Skewness & 0.914 & 0.018 & -0.028 & 0.707 \\
\hline Kurtosis & 2.496 & 1.308 & 1.604 & 2.541 \\
\hline Sum & 1045619. & 85071095 & 454.0395 & 1507.250 \\
\hline Observations & 29 & 29 & 29 & 29 \\
\hline
\end{tabular}

Table 1: Descriptive Statistics of variables

Source: Authors Computation using E-view 10

From Table 1, the result of the descriptive statistics showed that gross domestic product, oil revenue and domestic price of petrol averaged N36.1 trillion, N2.9 trillion and N51.97 respectively. GDP grew to a maximum of N127.76trillion,oil revenue recorded a maximum value of N6.53 trillion while domestic price of petrol recorded a maximum value of N145. The standard deviation calculated for oil revenue was the most volatile in the series with a 
value of 2355935.0 while oil rent was the least volatile variable with a value of 11.11 . The calculated values for the skewness statistics value of oil rent was negative, suggesting that its distribution has a long left tail while GDP, oil revenue and domestic price of petrol variables were positively skewed, suggesting that their distributions have a long right tail. Also, the kurtosis statistics of all the variables were platykurtic, suggesting that their distributions were flatter than a normal distribution. These observations suggest the existence of a unit root in the series. Thus, estimate these variables at level strength not give good quality results. It is therefore imperative to conduct the unit root test to check the stationary characters of the variables. In this study, the Augmented Dickey Fuller (ADF) unit root test procedure was adopted.

\subsection{Unit root Test Result}

The Unit root test for stationary was conducted and the result is presented below.

Augmented Dickey-Fuller (ADF) Test

\begin{tabular}{|c|c|c|c|c|c|}
\hline $\begin{array}{l}\text { Vari } \\
\text { able }\end{array}$ & Level & $\begin{array}{c}5 \% \text { Critical } \\
\text { Value }\end{array}$ & $\begin{array}{l}1^{\text {st }} \\
\text { Differenc } \\
\text { e }\end{array}$ & $\begin{array}{c}5 \% \\
\text { Critical } \\
\text { Value }\end{array}$ & $\begin{array}{l}\text { Decisio } \\
\text { n }\end{array}$ \\
\hline $\begin{array}{l}\text { LGD } \\
\mathrm{P}\end{array}$ & $\begin{array}{l}- \\
4.43419 \\
3\end{array}$ & -2.971853 & & & $\mathrm{I}(0)$ \\
\hline $\begin{array}{l}\text { LOR } \\
\text { V }\end{array}$ & $\begin{array}{l}- \\
2.06583 \\
2\end{array}$ & -2.971853 & $\begin{array}{c}- \\
5.513296\end{array}$ & -2.976263 & $\mathrm{I}(1)$ \\
\hline $\begin{array}{l}\text { LOR } \\
\mathrm{T}\end{array}$ & $\begin{array}{l}- \\
2.08156 \\
8\end{array}$ & -2.976263 & $\begin{array}{c}- \\
5.000656\end{array}$ & -2.976263 & $\mathrm{I}(1)$ \\
\hline $\begin{array}{l}\text { LDP } \\
\mathrm{P}\end{array}$ & $\begin{array}{l}- \\
2.76496 \\
4\end{array}$ & -2.971853 & $\begin{array}{c}- \\
3.816418\end{array}$ & -2.976263 & $\mathrm{I}(1)$ \\
\hline
\end{tabular}

Table 2: Unit Root Test Results for Stationary

Source: Authors Computation using E-view 10

Data on each series were tested for stationary in other to avoid a spurious regression. For this study, the Augmented Dickey-Fuller (ADF) was used to test the null hypothesis of a unit root at 5 percent significance level. The null hypothesis of a unit origin is discarded in favour of the motionless alternative in each case if the test statistic is more negative than the dangerous value. A rejection of the null hypothesis means that the series do not have a unit root. The result of the test as shown in table 2 above shows that all variables were stationary after first difference except the log of GDP which attained stationary at levels. Since the variables are integrated at order one, we then proceed to conduct the co-integration test.

\subsection{ARDL Form and Bounds Test Results}

Performing the co-integration test is necessary in order to establish whether or not, a long run relationship exists between the variables. However, since the unit root test conducted showed that the series were integrated of different order, I(0) and I(1), the bounds test proposed by Pesaran, Shin and Smith was appropriate. The Long Run Autoregressive Distributed Lagged Form and Bounds Test for co-integration on each model were conducted and presented below;

\begin{tabular}{|l|c|c|}
\hline Test statistic & Value & K \\
\hline F-statistics & 10.13 & 3 \\
\hline
\end{tabular}

\section{Critical value bounds}

\begin{tabular}{|l|c|c|}
\hline Significance & I0 Bound & I1Bound \\
\hline $10 \%$ & 2.72 & 3.77 \\
\hline $5 \%$ & 3.23 & 4.35 \\
\hline $2.5 \%$ & 3.69 & 4.89 \\
\hline $1 \%$ & 4.29 & 5.61 \\
\hline
\end{tabular}

(C) 2019, IJSMS 
Table 3: ARDL Bounds Test Result

Source: Authors Computation using E-view 10

As presented in the table above, the analysis of the long run relationship between gross domestic product and the underlying independent variables are seen. The computed F-statistics (10.13) is greater than the upper bound critical values at 5 percent significance level, (4.35). Hence, the null hypothesis of no levels relationship will not be accepted. It is therefore concluded that there is long run relationship between the variables.

\subsection{Long Run Coefficient}

Following the mixed integration of our series, the ARDL was applied and the results are shown in the table below;

Dependent Variable: LGDP

\begin{tabular}{|c|r|r|r|c|}
\hline Variable & Coefficient & $\begin{array}{r}\text { Std. } \\
\text { Error }\end{array}$ & $\begin{array}{r}\text { t- } \\
\text { Statistic }\end{array}$ & Prob. \\
\hline LORV & 0.422261 & 0.476191 & 0.886747 & 0.3983 \\
\hline LORT & 0.285479 & 0.343976 & 0.829941 & 0.4280 \\
\hline LDPP & 0.228851 & 0.567619 & 0.403177 & 0.6962 \\
\hline C & 0.573512 & 0.066265 & 8.654788 & 0.0000 \\
\hline
\end{tabular}

Table 3: Long Run Coefficient Test Result

Source: Authors Computation using E-view 10

Table 3 depicts the result of the estimated long run coefficients. The selected ARDL here is ARDL 2334 based on the Akaike Info Criterion (AIC). From the results, all the variables had their outcomes in line with theoretical expectations except the domestic price of petrol a though they were not statistically significant at the conventional levels. Theoil revenue coefficient was positive implying that a unit increase in oil revenue results to a 0.42 units increase in GDP. This was in line with the study by Adedokun (2012), Ogbonna\&Appah (2012) and Nwoba\&Abah (2017) which showed a positive relationship between oil revenue and GDP in Nigeria. The implication of this is that oil revenueimproved economic growth in the long run. Oil rent exerted a positive relationship with GDP as expected a priori. This shows that a percentage rise in oil rent would increase gross domestic product by0.23 percent. The impact of the domestic price of petrol on GDPwas positive in the long run contrary to theoretical expectation implying that a unit increase in the domestic price of petrolraisesgross domestic product by 0.22 units in Nigeria.

\subsection{Short Run Coefficient}

The result of the short run dynamic model of balance of trade is depicted in table below.

\section{Dependent Variable: LGDP}

\begin{tabular}{|c|c|c|c|c|}
\hline Variable & Coeff. & $\begin{array}{r}\text { Std. } \\
\text { Error }\end{array}$ & t-Statistic & Prob. \\
\hline $\mathrm{D}($ LGDP(-1)) & -0.499747 & 0.142138 & -3.515921 & 0.0066 \\
\hline $\mathrm{D}($ LORV) & -0.016977 & 0.028046 & -0.605321 & 0.5599 \\
\hline $\mathrm{D}($ LORV(-1)) & -0.147663 & 0.030173 & -4.893930 & 0.0009 \\
\hline $\mathrm{D}($ LORV(-2)) & -0.095314 & 0.031912 & -2.986744 & 0.0153 \\
\hline $\mathrm{D}($ LORT) & -0.013566 & 0.012747 & -1.064242 & 0.3149 \\
\hline $\mathrm{D}($ LORT(-1)) & -0.064722 & 0.014927 & -4.335788 & 0.0019 \\
\hline $\mathrm{D}($ LORT(-2)) & -0.072543 & 0.016029 & -4.525713 & 0.0014 \\
\hline $\mathrm{D}($ LDPP) & 0.088531 & 0.038165 & 2.319671 & 0.0455 \\
\hline $\mathrm{D}($ LDPP(-1)) & 0.093352 & 0.024179 & 3.860828 & 0.0038 \\
\hline $\mathrm{D}($ LDPP(-2)) & 0.168932 & 0.027442 & 6.156070 & 0.0002 \\
\hline $\mathrm{D}($ LDPP(-3)) & 0.104986 & 0.029147 & 3.602010 & 0.0057 \\
\hline ECM(-1)* & -0.155188 & 0.021117 & -7.348957 & 0.0000 \\
\hline
\end{tabular}

$\mathrm{R}^{2}=0.95, \mathrm{R}^{2}$ - adjusted $=0.90$, F-stat $=18.67$, F-Prob. $=0.00$ 
Table 5: Summary of the short-run ECM

Source: Authors Computation using E-view 10

Gross domestic product (GDP) in the one lagged period appeared with a negative sign implying that GDP in the previous year contributes negatively to its current year's value. Oil revenue in its current period, lag one and lag two periods impacted negatively on GDP although not significantly in its current period contrary to a priori expectation and the long run result. This is consistent with the findings of Baghebo and Atima (2013) and contrary to the findings of Adedokun (2012), Ogbonna\&Appah (2012) and Nwoba\&Abah (2017). The implication of this is that in the short run, oil revenue retarded economic growth in Nigeria for the period covered by the study.Similarly,in the current period, first and second lagged periods, oil rent exerted a negative impact on GDP in Nigeria in line with the submission of Fuinhas, Marques \&Couto (2015). These findings suggest that the resource curse thesis was valid in the Nigerian economy in the short run. Domestic price of petrol on the other hand had a significant and positive impact on gross domestic product in Nigeria for its current period, lags one, two and three periods in line with the long run result. The coefficient of the error correction term appeared with the right sign and was significant at 1 percent level indicating that about 15 percent of any disequilibrium in the previous year is reconciled in the current year. In other words, the divergence from short run to long run equilibrium in GDP was 15 percent in a year. The goodness of fit of 0.95 implies that $95 \%$ of the total variation in gross domestic product is accounted for by changes in oil revenue, oil rent and domestic price of petrol in Nigeria.

\subsection{Diagnostic Test}

A summary of the diagnostic tests is reported in the table below

\begin{tabular}{|l|l|l|l|}
\hline Test & F-statistic & Prob. & Conclusion \\
\hline Jarque-Bera & 1.185812 & 0.552719 & $\begin{array}{l}\text { Normally } \\
\text { Distributed }\end{array}$ \\
\hline $\begin{array}{l}\text { Breusch-Godfrey } \\
\text { Serial Correlation } \\
\text { LM }\end{array}$ & 1.817926 & $\begin{array}{l}\mathrm{F}(2, \\
0.2313\end{array}$ & $\begin{array}{l}\text { No Serial } \\
\text { Correlation }\end{array}$ \\
\hline $\begin{array}{l}\text { ARCH } \\
\text { Heteroskedasticity }\end{array}$ & 0.333528 & $\begin{array}{l}\mathrm{F}(1, \quad 22) \\
0.5695\end{array}$ & $\begin{array}{l}\text { No } \\
\text { heteroskedastici } \\
\text { ty }\end{array}$ \\
\hline Ramsey RESET & 0.771411 & $\begin{array}{l}\mathrm{F}(1, \\
0.4054\end{array}$ & $\begin{array}{l}\text { No specification } \\
\text { errors }\end{array}$ \\
\hline
\end{tabular}

Table 6: Summary of the Diagnostics Test

Source: Authors Computation using E-view 10

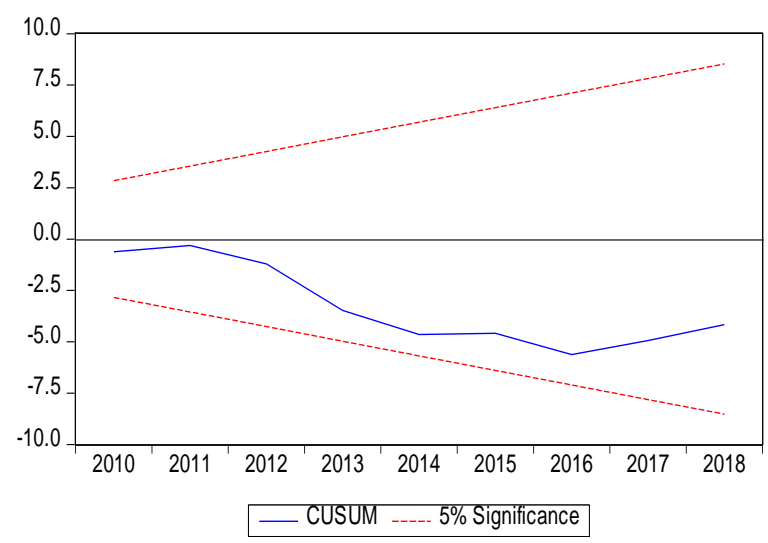




\section{Figure 1: $\quad$ CUSUM Test of Stability}

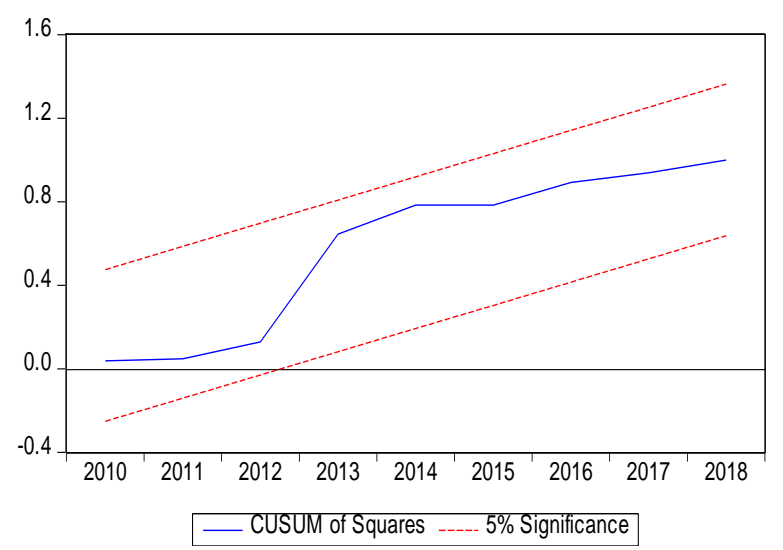

\section{Figure 2: $\quad$ CUSUMSQ Test of Stability}

An observation from the results of the diagnostic test in Table 6 shows that the model scaled through the diagnostic tests as they reveal a probability value greater than 0.05 implying that the null hypotheses of normal distribution, no serial correlation, no heteroscedasticity and no specification errors are accepted based on the Jarque-Bera normality test result, Breusch-Godfrey serial correlation LM result, ARCH test result and Ramsey RESET tests respectively. Also, the stability of the parameters of the model was examined using the plots of the cumulative sum of recursive residuals (CUSUM) and cumulative sum of squares of recursive residual (CUSUMSQ). The CUSUM and CUSUMSQ in figures 2 and 3 stayed within the 5 percent critical line, indicating the constancy or stability of the regression estimates throughout the period covered by the study.

The study examined the effectsof oil revenue on economic growth in Nigeriabetween 1980 and 2017. Time series data were sourced from secondary sources on Gross Domestic Product, Oil Revenue, Oil Rent and Domestic Price of Petrol. The analysis started by analyzing the descriptive statisticsof the series and proceeded to examination of the stochastic characteristics of each time series by testing their stationary using Augmented Dickey-Fuller test. The ARDL model was used to estimate the coefficients of the parameters for both the short-run and the long-run. The Fstatistics obtained from the bounds co-integration test shows a stable long run relationship between the variables. Findings from the study showed that in the long run, oil revenue and oil rent impacted on GDP positively although not significantly. In the short run however, both variables retarded economic growth in Nigeria. This goes a long way to show that the enormous windfall from crude oil in the nation has been mismanaged. The domestic price of petrol of petrol impacted positively on economic growth both in the long run and short run. The study therefore recommends a judicious use of the revenue generated from the oil sector to provide long term sustainable economic growth. In addition, due to the volatility and uncertainty in the oil sector in Nigeria, government should embark on a realistic diversification plan to alternative sectors of the economy to enhance the productive base of the nation seeing that crude oil is an exhaustible asset. Furthermore, government through its agencies should properly regulate the pump price of petroleum.

\section{REFERENCES}

[1] Adedokun, J. A. (2012). Oil Export and Economic Growth: Descriptive Analysis and Empirical Evidence from Nigeria. Pakistan Journal of Social Sciences. 9(1), 46-58

[2] Agnihotri, G. (2015). How Much Does OPEC Really Earn? Retrieved on 12th October, 2019 from www.oilprice.com/Energy/EnergyGeneral/How-Much-Does-OPEC-Really-Earn.html

[3] Akanni, O. P. (2007). Oil Wealth and Economic Growth in Oil Exporting African Countries AERC Research paper, 170, Nairobi.

[4] Akinlo, A. E. (2012). How important is Oil in Nigeria"s Economic Growth? Journal of SustainableDevelopment, 5(4) 
[5] Alley, I., Asekomeh, A., Mobolaji, H. \&Adeniran, Y. (2014).Oil Price Shocks and Nigerian Economic Growth.European Scientific Journal, 10(19)

[6] Aregbeyen, O. \&Kolawole, B. O. (2015).Oil Revenue, Public Spending and Economic Growth Relationships in Nigeria.Journal of Sustainable Development, 8(1), 113 - 123

[7] Attamah, N. (2015). The Impact of Oil Wealth on Economic Growth of aMonocultural Economy-Nigeria.International Journal of Economics, Commerce and Management,3(5) 838-853

[8] Auwal, U. \&Mamman, J. A. (2012). The Downstream Sector: An Assessment of Petroleum Products Supply in Nigeria. JEL Classification: L78, Q30, D40, D22, C51

[9] Baghebo, M. and Atima, T.O. (2013).The impact of petroleum on economic growth in Nigeria.Global Business and Economics Research Journal, 2(5), 102-115

[10] Central Bank of Nigeria (2018). Annual Reports and Statement of Accounts, CBN Abuja, Nigeria

[11] Collier P., Elliot L.H., Hoeffler A., Reynal-Querol M. \&Sambanis N. (2003).Creaking the Conflict Trap, Civil War and Development Policy: World Bank and Oxford University Press.

[12] Eravwoke, K. E. E., lobari, C. M. and Ukavwe, A. (2014). Crude Oil Export and its Impact in Developing Countries: A Case of Nigeria. Global Educational Research Journal, 2(6), 80-92

[13] Ewubare, D. B. \&Obayori, E. L. (2019).Comparative Study of the Impact of Oil Rent on Healthcare in Nigeria and Cameroon: A Three Stage Methodical Approach. International Journal of Science and Management Studies, 2(1), 58-63

[14] Ewubare, D. B. \&Uzoma, C. N. (2019).An Appraisal of Stabilization Policy Measures and its Implication on Balance of Trade in Nigeria.International Journal of Economics and Management Studies, 6(9), 161-169

[15] Fearon, J.D. \&Laitin D.D. (2003).Ethnicity Insurgency and Civil War.America Political Science Review, 97(1) 75-90.

[16] Fuinhas, J. A., Marques, A. C., \&Couto, A. P. (2015). Oil Rents and Economic Growth in Oil Producing Countries: Evidence from a Macro Panel. Economic Change and Restructuring, 48(3), 62-73

[17] Maku, O. E., Adetowubo-King, S. A.,\&Aduralere O., O. (2018).Impact of Petroleum Product Price on Human Welfare in Nigeria.PERIODYK NAUKOWY AKADEMII POLONIJNE, 9 (4),27-42

[18] National Bureau of Statistics (2014). Review of the Nigerian Economy (Abuja: FCT).

[19] Nigerian National Petroleum Corporation (2010). Annual Statistical Bulletin, January - December 2010, Abuja, Corporate Planning and Development Division (CPDD).

[20] Nwoba M. O. E. (2017). Impact of Crude Oil Revenue (COR) On Economic Growth in Nigeria (1960-2010). Journal Of Humanities And Social Science, 22(7), 85-99

[21] Odularu, G.O. (2008). Crude Oil and the Nigerian Economic Performance.http://www.ogbus.ru/eng/ Accessed 25/08/2019

[22] Ogbonna, G. N. \&Ebimobowei.A. (2012).Impact of Petroleum Revenue and the Economy of Nigeria.The Social Sciences, 7: 405-411

[23] Ogundipe, O. M. Ojeaga, P. \&Ogundipe, A. A. (2014).Oil Price and Exchange Rate Volatility in Nigeria.Journal of Economics and Finance, 5(4), 1 -9

[24] Ojapinwa, T. V. \&Ejumedia, P. E. (2012). The industrial impact of oil price shocks in Nigeria (1970-2010). European Scientific Journal , 8(12), 93-106

[25] Oladipo, S. O. \&Fabayo, J. O. (2012).Global Recession, Oil Sector and Economic Growth in Nigeria.Asian Transactions on Basic and Applied Sciences, 1(6)

[26] Olayungbo, D. O. \&Adediran,K. A. (2017).Effects of Oil Revenue and Institutional Quality on Economic Growth with an ARDL Approach.Journal of Energy and Policy Research. 4(1), 44-54

[27] Opaleye, S.S., Okowa, W. \&Ohale, L. (2018). Oil Rent and Socioeconomic Outcomes in Selected oil Producing Countries in Africa.International Journal of Research in Business, Economic and Management, 2(2), 27-43

[28] Organization of the Petroleum Exporting Countries (2006).Annual Statistical Bulletin. Vienna: Ueberreuter Print und Digimedia.

[29] Pesaran, M., Shin, Y., \& Smith, R. J. (2001).Bounds Testing Approaches to the Analysis of Level of Relationship.Journal of Applied Econometrics, 16(3): 289-326.

[30] Subramanian, A. \&Sala-i-Martin, X. (2003). Addressing the Natural Resource Curse: An Illustration from Nigeria. IMF Working Paper 